\title{
НЕСКОЛЬКО ЗАМЕЧАНИЙ О ДВУЗУБЦЕ ИЗ МОГИЛЬНИКА БОДЗЯ В ЦЕНТРАЛЬНОЙ ЧАСТИ ПОЛЬШИ
}

\begin{abstract}
Резюме: При раскопках могильника близ дер. Бодзя (Куявско-Поморское воеводство, Польша) в погребении E-864/I был найден поясной набор. На одной из сторон наконечника, входящего в этот набор, помещено изображение так называемого „знака Рюриковичей” - двузубца, древнерусского княжеского герба. Анализ геральдических особенностей знака показал, что изготовление поясной гарнитуры из погребения следует относить ко времени туровского княжения Святополка Ярополчича, то есть - к 1008-1013 гг. Не исключено, что погребенный в могиле Е-864/I молодой воин был мечником князя Святополка.
\end{abstract}

Ключевые слова: воинское погребение, поясная гарнитура, двузубец, знак Рюриковичей, мечник.

При раскопках в 2007-2009 гг. могильника эпохи викингов близ дер. Бодзя (Куявско-Поморское воеводство, Польша) в воинском погребении Е-864/I был найден поясной набор (Bodzia 2014, s. 215-216 [W. Duczko], fig. 10.13-10.15). На одной из сторон наконечника, входящего в этот набор, помещено изображение двузубца. Правый зубец двузубца увенчан крестовидной фигурой, ниже треугольной ножки размещена волютообразная фигура (рис. 1). Найденный в погребении меч типа Z (Bodzia 2014, s. 183 [M. Kara], fig. 9.3) датируется концом X - первой половиной XI вв. (Петерсен 2005, с. 202-204; Кирпичников 1966, с. 34; Андрощук 2013, с. 78-80). Очевидно, к этому же времени следует относить и совершение захоронения.

Комментируя двузубец на поясном наконечнике из Бодзи В. Дучко справедливо отнес его к древнерусским княжеским знакам - так называемым «знакам Рюриковичей». Исследователь атрибуировал двузубец русскому князю Святополку Ярополчичу (Bodzia 2014, s. 215-216 [W. Duczko]), посмертному сыну Ярополка Святославича, пасынку Владимира Святославича (Войтович 1992, с. 21). Аналогичными знаку из Бодзи В. Дучко считал изображения двузубца на монетах Святополка и на стороне «Б» геральдической подвески из раскопок в Пскове в 1976 г. (Bodzia 2014, s. 216-217 [W. Duczko], fig. 10.16),

* Институт истории материальной культуры Российской Академии наук, Dvortsovaya Emb., 18, Saint Petersburg, 191186, Russian Federation. e-mail: serge_beletsky@mail.ru. 


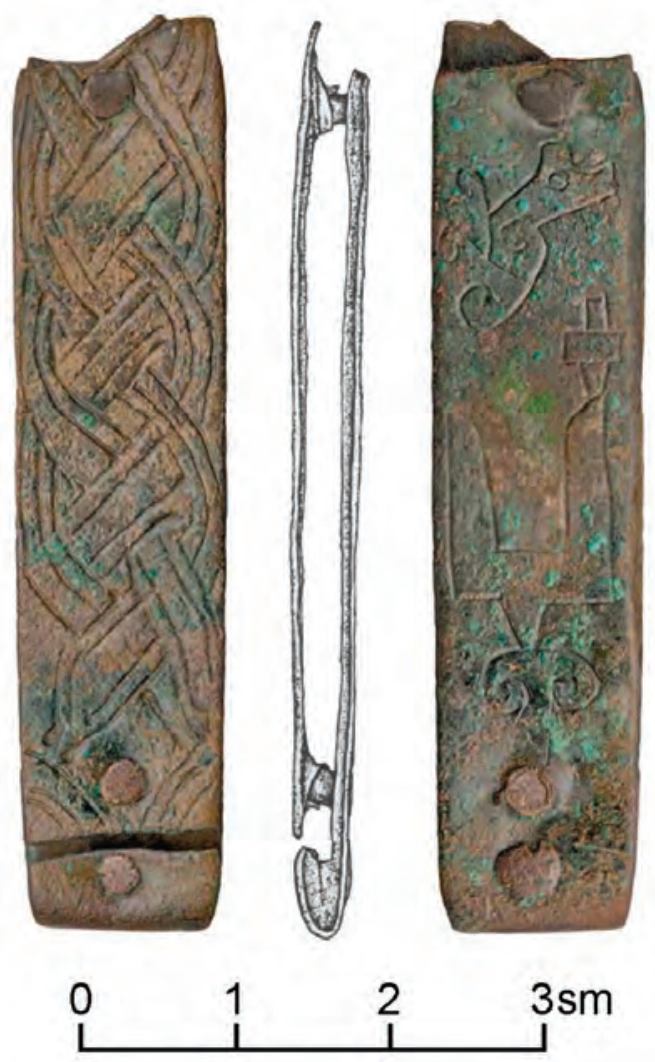

Рис. 1. Поясной наконечник из погребения Е-864/I в могильнике Бодзя, По: Bodzia 2014, s. 215-216, fig. 10.13-10.15

а в качестве параллелей для волютообразной фигуры, размещенной под ножкой двузубца, указал на сарматские знаки Северного Причерноморья первых веков н. э. и на буквы глаголического алфавита (Bodzia 2014, s. 217-218 [W. Duczko], fig. 10.17). Однако, между сарматскими тамгами (Соломоник 1959, с. 168-169; см. также: Ольховский 2001; Яценко 2001) и двузубцем из Бодзи зияет полутысячелетняя хронологическая лакуна, так что отмеченные параллели представляют не более чем академический интерес. Что же касается букв глаголического алфавита, то их сходство с изображением на поясном наконечнике из Бодзи, на мой взгляд, сомнительное (ср.: Черепнин 1956, с. 96-98, табл. 1). По-видимому, волютообразная фигура, примыкающая к ножке двузубца, не имеет отношения к самому двузубцу, а является отдельным изображением, симметричным зооморфному изображению, размещенному над зубцами двузубца. Замечу, что при нанесении на пластину наконечника зооморфного изображения мастер также использовал волютообразные элементы. 


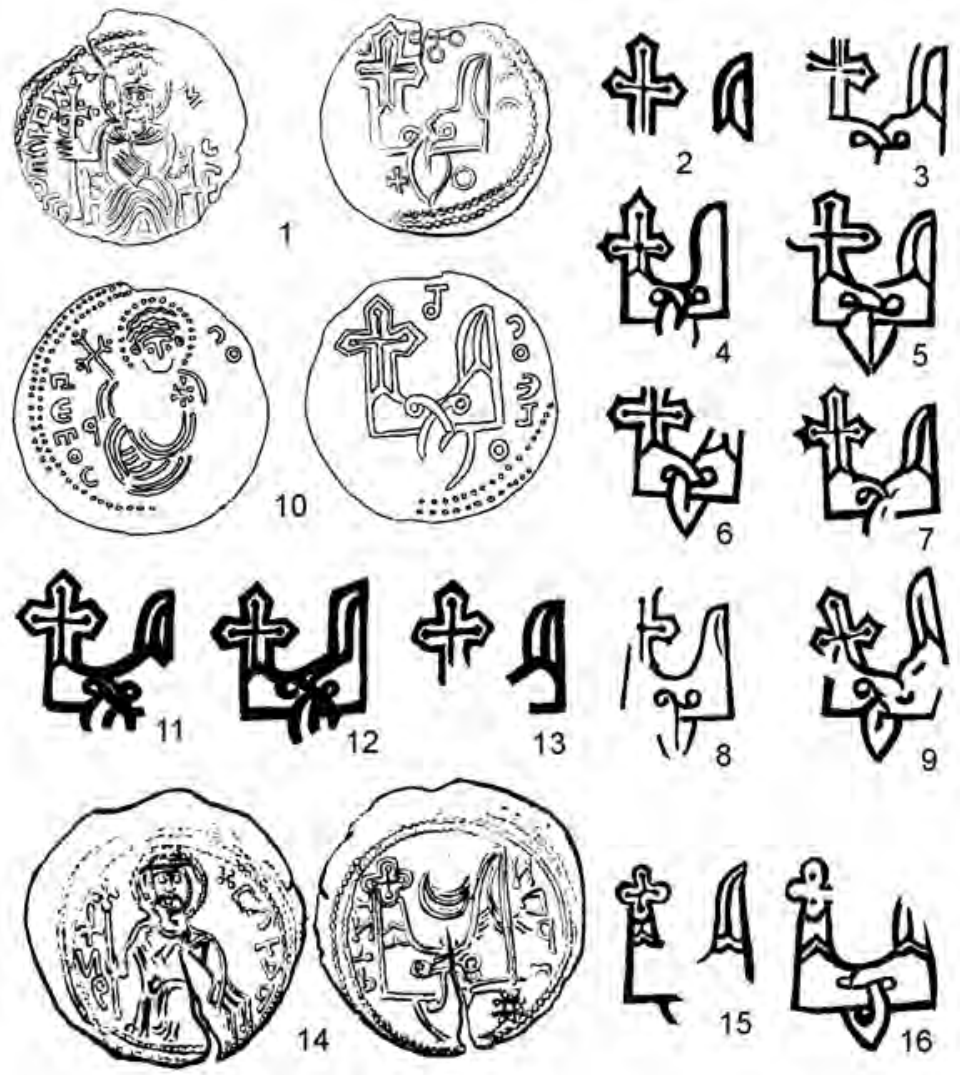

Рис. 2. Изображения на монетах Святополка Ярополчича: 1-9 - с именем „Святополк”; 10-13 - с именем „Петрос”; 14-16 - с именем „Петор”. По: Белецкий 2000а, с. 19-23, рис. 9-10; 2000б, с. 374-376, рис. 9-10

Крестообразную фигуру, завершающую правый зубец двузубца из Бодзи, В. Дучко сопоставил с крестом на зубце у двузубца, помещенного на монетах князя Святополка Ярополчича. У знака на монетах с именем Святополка (рис. 2:1-9) и с именем Петрос (рис. 2:10-13) один из зубцов двузубца имеет крестовидную форму (Сотникова, Спасский 1983, с. 82-90), что является принципиальным отличием от двузубца из Бодзи, у которого крестовидная фигура увенчивает зубец. Крестик на вершине зубца (рис. 2:14-16) зафиксирован только на монетах с именем Петор (Сотникова, Спасский 1983, с. 90-96). По мнению И. И. Синчука, такое размещение крестика на зубце связано с особенностями изготовления монетных штемпелей, образцом для которых послужил дефектный экземпляр монеты с именем Петрос или с именем Святополка (Синчук 1994, с. 231-235). Таким образом, не исключено, что появление на монетах с именем Петор крестика на вершине 


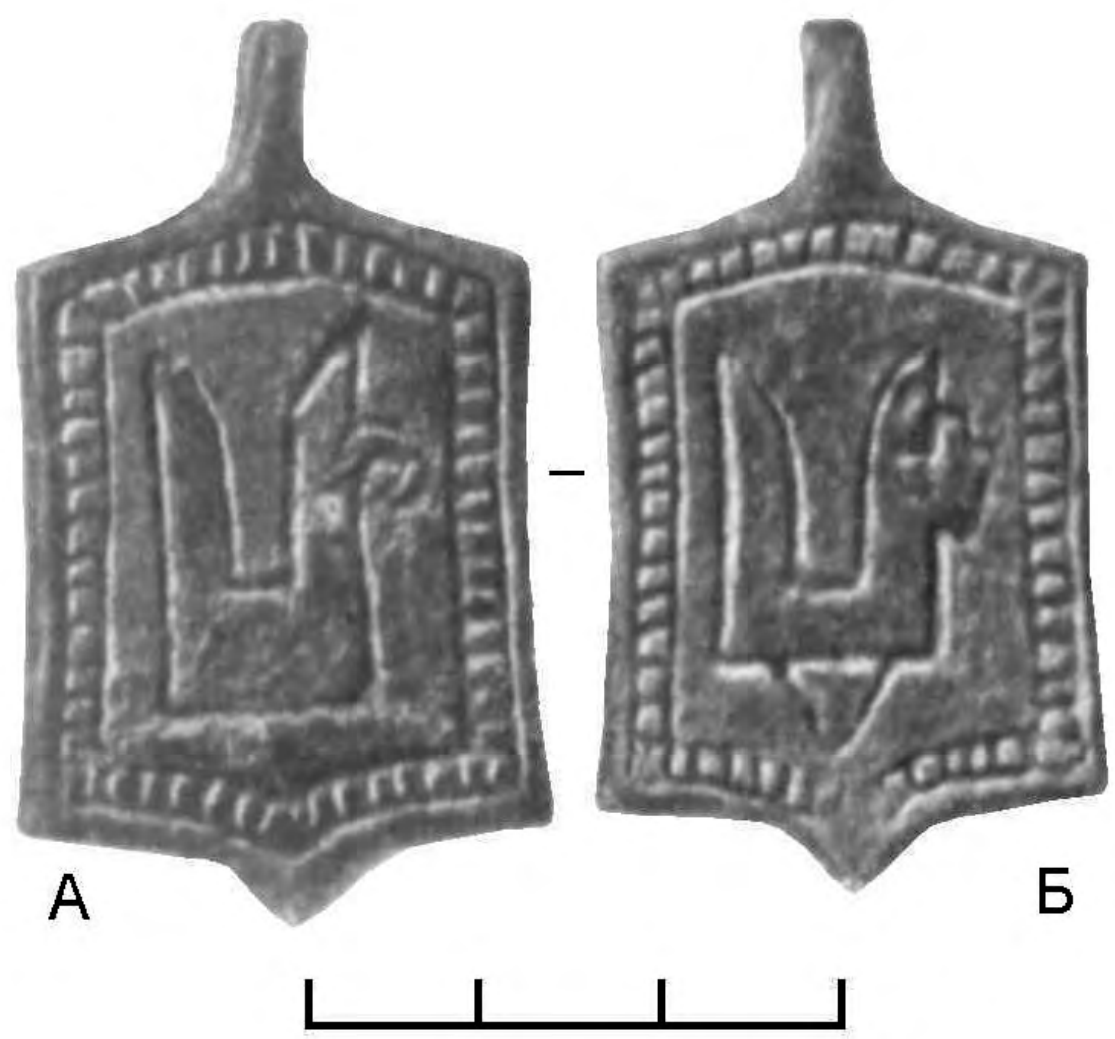

Рис. 3. Геральдическая подвеска из раскопок в Пскове в 1976 г., По: Лабутина 1983, с. 17,21 , рис. 10

зубца двузубца вместо полноценного перекрестия объясняется случайными обстоятельствами.

Но дело даже не в этом. У двузубца на монетах Святополка Ярополчича крестовидным либо увенчанным крестиком был левый, а не правый зубец1. Это не позволяет считать знаки на монетах аналогичными знаку из Бодзи.

Не имеет отношения к двузубцу из Бодзи и знак на стороне «Б» псковской подвески (рис. 3). Двузубцы с перекрестием на правом зубце известны по

1 В брошюре 2000 г. и ее дополненном варианте, опубликованном в журнале „Стратум плюс”, в тексте имеется опечатка: „Святополк пользовался двузубцем с крестовидным правым зубцом” (Белецкий 2000а, с. 49; 2000б, с. 390) Конечно, правильное чтение должно было быть „Святополк пользовался двузубцем с крестовидным левым зубцом”, как это и следует из развернутых комментариев к знакам Святополка (Белецкий 2000а, с. 19-23; 2000б, с. 374-376). К сожалению, опечатка осталась не исправленной, а впоследствии ввела в заблуждение Т. Крыштофяк, повторившую ее в своей статье (Krysztofiak 2013, s. 121). Пользуюсь случаем извиниться перед коллегами и исправить ошибку. 

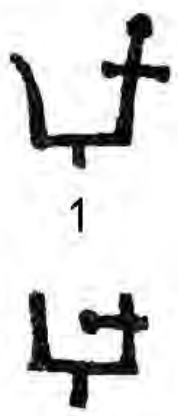

5

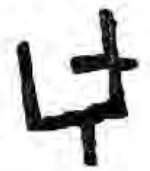

2

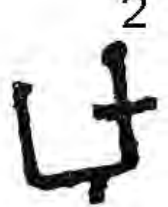

6

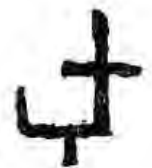

3

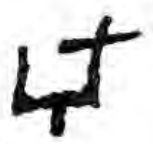

7

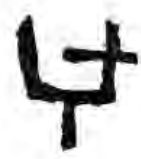

4
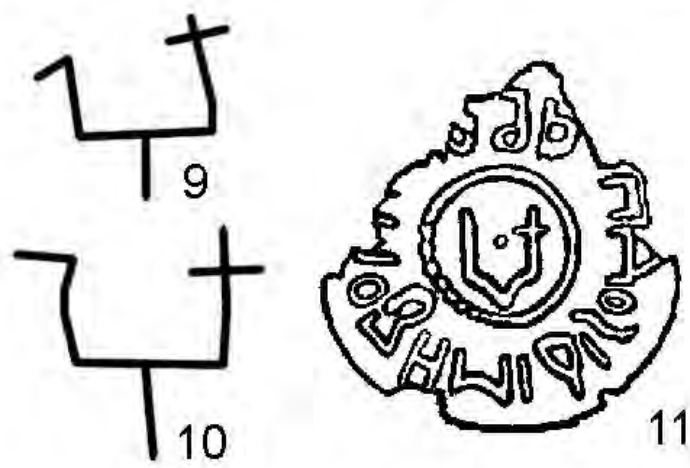

Рис. 4. Двузубцы на дрогичинских пломбах (1-7) и печати (8), на берестяном туеске из Гродно (9-10) и на т.н. „таманском брактеате” (11), По: Белецкий 2001, с. 62; Молчанов 1982, c. $223-226$

изображениям (рис. 4:1-8) на дрогичинских пломбах и печати (Белецкий 2001, c. 62, тип I/2/5). Такой же знак дважды процарапан (рис. 4:9-10) на берестяном туеске из Гродно (Трусауิ, Собаль, Здановіч 1993, мал. 100). Но все эти предметы датируются XII-XIII вв. Правда, А.А. Молчанов датировал началом XI в. т. н. «таманский брактеат» (рис. 4:11) и считал двузубец на этом предмете знаком Мстислава Тмутараканского $(† 1036)^{2}$. Основанием для ранней датировки, по мнению исследователя, является треугольная форма ножки двузубца, характерная для знаков X - начала XI в. (Молчанов 1982, с. 223-226). Этот вывод недавно повторила и Э. В. Королева (2016, с. 88-90). Однако, треугольная ножка известна и у двузубцев XII-XIII вв. (Белецкий 2001,

2 Знаком Мстислава Тмутараканского, по моему мнению, являлся трезубец, центральный зубец у которого имеет ромбовидное завершение (Белецкий 2000а, с. 57-60; 2000б, с. 393-394). 


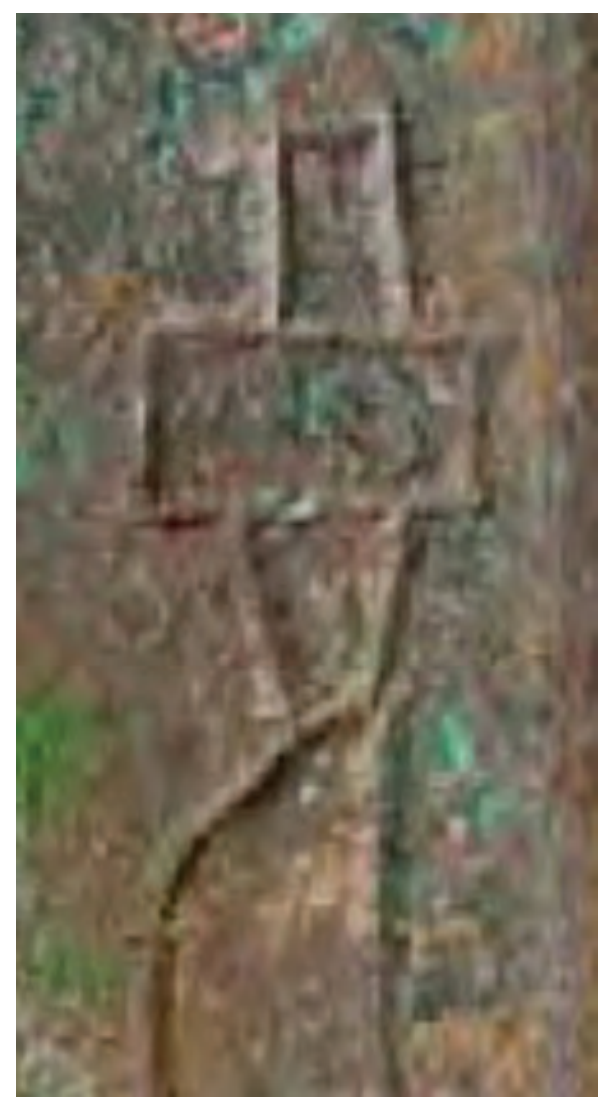

Рис. 5. Крестовидная фигура на поясном наконечнике из могильника Бодзя, По:

Bodzia 2014, s. 216, fig. 10.15

табл. 18:3; 2014a, рис. 7:6, 7; Медведев 1959, с. 135, рис. 7:5), так что датировка «таманского брактеата» временем ранее XII-XIII вв. маловероятна ${ }^{3}$.

Заметим, что у двузубца на стороне «Б» псковской подвески крестовидный значок размещен не на вершине, а на середине зубца и, фактически, имеет вид крестовидного отрога наружу. Считать такой отрог аналогичным перекрестию на зубце я бы не решился.

Добавлю к сказанному, что датировка псковской подвески с момента ее обнаружения и вплоть до настоящего времени остается предметом дискуссии (Лабутина 1983, с. 17, 21, рис.10; Молчанов 1986, с. 185; Белецкий 1996,

3 Отмечу, кстати, что подлинность появившихся на российском антикварном рынке в последние годы новых экземпляров „таманских брактеатов” (напр.: Бабаев 2009, с. 76-77), представляется мне крайне сомнительной. 
с. 84-85, примеч. 23; 2004, с. 273-277; 2016, с. 92-97; Лабутина, Королева 2014, с 171-195; Королева 2016, с. 79-91), так что использовать знаки на этой подвеске в качестве опорных аналогий для двузубцев X-XI вв., по меньшей мере, рискованно.

Возвращаясь к двузубцу из могильника Бодзя отмечу, что зубцы этого знака разновелики: правый зубец за счет крестобразной фигуры на треть длиннее левого зубца. Подобная ассиметрия в изображениях двузубцев X-XI вв. мне не встречалась. Замечу также, что крестобразная фигура определенно не является естественным продолжением правого зубца: она смещена влево относительно вершины зубца и опирается не на собственно вершину зубца, а на верхнюю часть его внутреннего контура (рис. 5), то есть, фактически, помещена не на зубце, а между зубцами двузубца, хотя и примыкает к правому зубцу.

После всего сказанного полагаю, что крестообразная фигура над правым зубцом у двузубца из Бодзи не только не является геральдически значимой частью знака, но и вообще не является частью княжеского знака: она примыкает к зубцу, подобно тому, как волютообразная фигура примыкает к ножке знака. Точно так же не имели геральдического значения дополнительные значки (крестик, „якорь”, полумесяц) между зубцами двузубца на монетах Святополка (рис. 2:1,10,14) и изображение ключа, размещенное между зубцами двузубца (рис. 6) на геральдической подвеске из раскопок камерного погребения в Пскове (Белецкий 2011, с. 47; ср.: Ершова, Яковлев 2016, с. 395-414).

Обращают на себя внимание контуры крестообразной фигуры (рис. 5): верхняя часть „мачты” и „перекладина” крестика представляют собой почти правильные прямоугольники, в то время как нижняя часть „мачты” имеет вид трапеции, обращенной короткой стороной вниз. Кроме того, левый контур нижней части „мачты” заметно смещен влево по сравнению с левым контуром верхней части, так что нижняя часть „мачты” не является продолжением верхней ее части. Судя по всему, крестообразная фигура на самом деле вообще не задумывалась как „крестик” - аналогиями для нее являются изображения клинкового оружия (рис. 7), вырезанные на деревянных цилиндрах из Новгорода (Янин 2001, № 6, 19, 20, 32, 35, 36, 40, 45) и на детском деревянном мече из Пскова (Гроздилов 1962, с. 56, рис. 43). Подобные изображения известны также среди граффити на восточных монетах и предметах X-XI вв. (Добровольский, Дубов, Кузьменко 1991, с. 54, 114, 116, рис. 54, рис. 13:1-2, 44:2). Правда, у большинства изображений мечей рукоять имеет навершие, а соотношение длины рукояти и клинка в тенденции соответствует настоящим мечам. Однако на деревянном мече из Пскова вырезано изображение меча с рукоятью без навершия (рис. 7:9), а у мечей, процарапанных на костяном изделии и на дне медной чаши из Тимерева (рис. 7:7,8) соотношение рукояти и клинка такое же, как и у изображения из Бодзи. Решусь предположить, что крестообразная фигура, примыкающая к правому зубцу двузубца из Бодзи, 


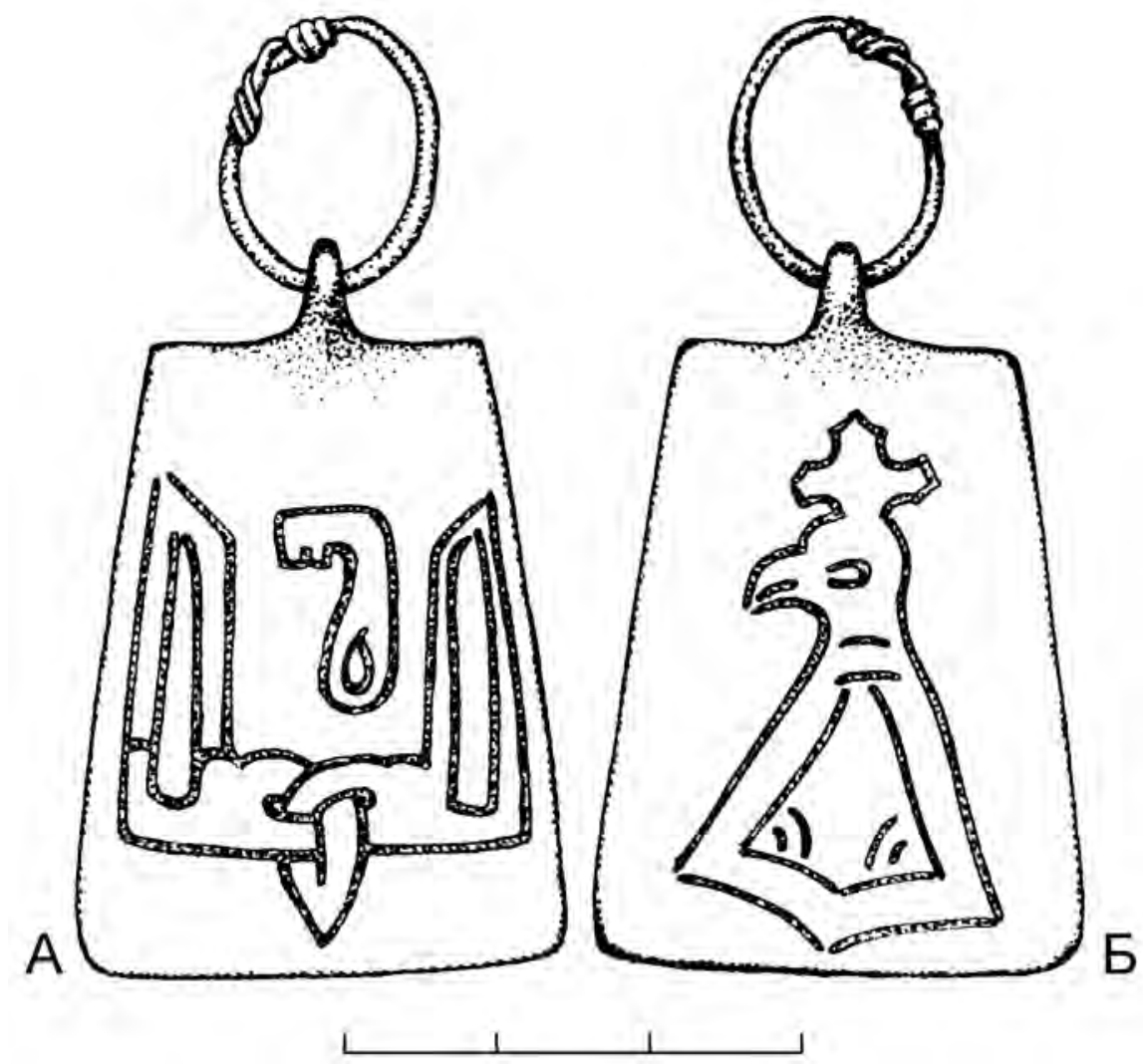

Рис. 6. Геральдическая подвеска из раскопок в Пскове в 2008 г., По: Ершова 2010, с. 287, рис. 3

представляет собой схематичное изображение меча, помещенное между зубцами двузубца.

Если все сказанное справедливо, следует признать, что на ременном наконечнике из Бодзи помещен обычный родовой двузубец Рюриковичей, лишенный каких бы то ни было дополнений и аналогичный двузубцам, известным по изображениям в граффити на восточных монетах (рис. 8-9).

Древнейшее из известных изображений двузубца на монетах - граффито № 72 свода 1991 г. (рис. 8:3). Оно зафиксировано на монете IX в. (?) из клада у д. Погорельщина (Беларусь), сокрытого после 903/904 г. (Добровольский, Дубов, Кузьменко 1991, с. 139, № 72). В. Н. Рябцевич полагал, что клад был сокрыт в 910-е годы (Археалогія 1993, с. 471), а Е.А. Мельникова датирует клад первым десятилетием Х в. (Мельникова 1996, с. 47; 1998, с. 176). Таким образом, знак на монете был процарапан, вероятнее всего, в годы великого княжения Игоря Рюриковича. 


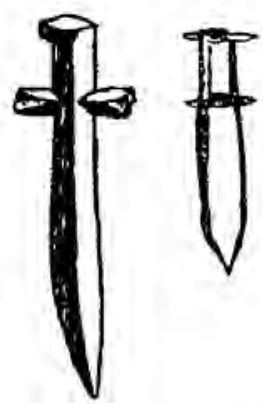

1

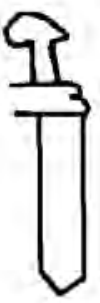

6
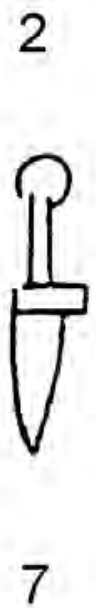

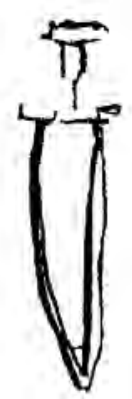

3
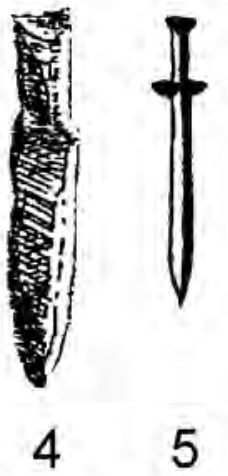

5
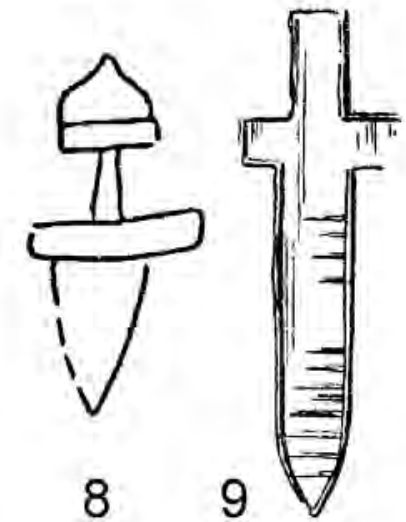

Рис. 7. Изображения мечей:

1-5 - на деревянных цилиндрах из Новгорода; 6 - на дирхеме 910-930 гг.; 7 - на костяном предмете из Тимерево; 8 - на бронзовой чаше из Тимерево; 9 - на детском деревянном мече из Пскова, По: Янин 2001, № 6, 19, 20, 32, 36; Добровольский, Дубов, Кузьменко 1991, с. 54, 114, 116, рис. $13,1,2,44,2$; Гроздилов 1962, с. 56 , рис. 43

Изображения двузубцев (рис. 8:4-6) процарапаны на монетах 913/914 (Добровольский, Дубов, Кузьменко 1991, с. 144, № 149), 919/920 (Мельникова 1996, с. 47, № 5) и 924/925 гг. (Добровольский, Дубов, Кузьменко 1991, с. 162, № 433). Граффити могли быть нанесены на монеты только после того, как сами монеты были отчеканены. И так как верхняя хронологическая граница участия этих монет в обращении не ясна, граффити могли появиться как в годы княжения Игоря Рюриковича, так и в годы княжения Святослава Игоревича (а, теоретически, даже позднее).

Родовой двузубец Рюриковичей и трезубец Владимира Святославича зафиксированы в граффити (рис. 9:2), процарапанных на подражании саманид- 


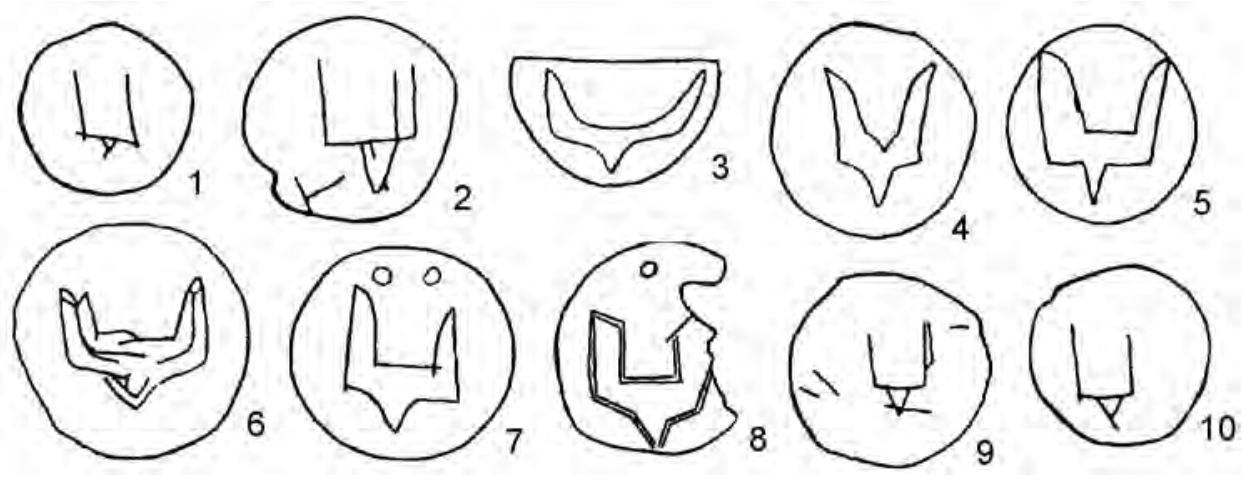

Рис. 8. Двузубцы в граффити на монетах, По: Белецкий 2000а, с. 41, рис. 16; 2000б, с. 385 , рис. 16

ским диргемам, происходящем из под Курска, Россия (Стародубцев, Лебедев 2015 , с. 163, рис. 3). Судя по сочетанию двузубца и трезубца, знаки были нанесены на монету в годы новгородского княжения Владимира Святославича (после 970), но - ранее гибели Святослава на Днепровских порогах $(972)^{4}$.

Вероятно, в годы великого княжения Святослава Игоревича были процарапаны также граффити (рис. 9:1) непроверенным сведениям, происходит с территории Черниговской области, Украина (Нечитайло 2012: 6, № 4). На лицевой стороне монеты, по мнению В. С. Кулешова ${ }^{6}$, удаётся прочитать остатки даты: Саманиды, Абд ал-Малик ибн Нух или (менее вероятно) Нух ибн Наср, 340-е гг. хиджры, то есть 952-960 гг. Е. Лемберг, на определение которого ссылается И. Ю. Сорокин (Сорокин 2015, с. 119), датирует монету 346 г. х., то есть - 958 г.

Граффити № 253 (рис. 8:7) свода 1994 г. (Нахапетян, Фомин 1994, с. 159) нанесено на монету 974/975 г. Этот двузубец не мог быть процарапан на

${ }^{4}$ Не исключено, что треугольная ножка двузубца, процарапанного на монете из под Курска, была дополнена раздвоением, частично уничтоженным пробитым в монете отверстием. Подобные раздвоения ножки ранее фиксировались в граффито № 329 свода 1994 г. (Нахапетян, Фомин 1994, с. 170, 207) и на роговом гребне с городища Иднакар в Удмуртии, Россия (Амелькин 1987, c. 107). Если раздвоенная часть ножки была процарапана осознанно, двузубец на монете принадлежал не Святославу, а его второму сыну, Олегу древлянскому, убитому по приказу старшего брата Ярополка в битве под Овручем в 977 г. (Белецкий 2000б, с. 389-390). В таком случае время нанесения знаков на монету определяется в интервале 970-977 гг. Впрочем, уверенности в том, что ножка у двузубца опиралась на осознанно выполненное раздвоение, у меня нет. С большим вероятием это раздвоение явилось следствием небрежности при нанесении граффито на монету.

${ }^{5}$ Комментарии к этим граффити см.: Белецкий 2017, с. 38-50.

${ }^{6}$ Благодарю В.С. Кулешова (Санкт-Петербург), сообщившего мне дату монеты. 


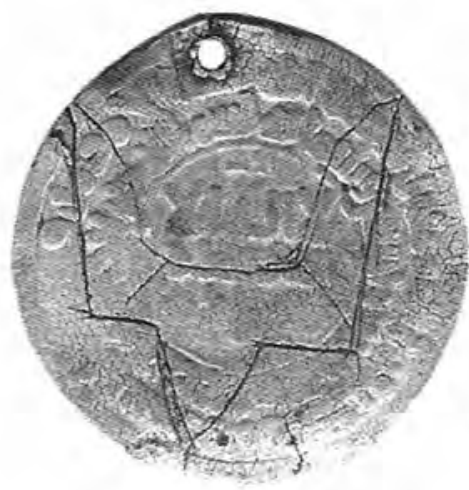

1
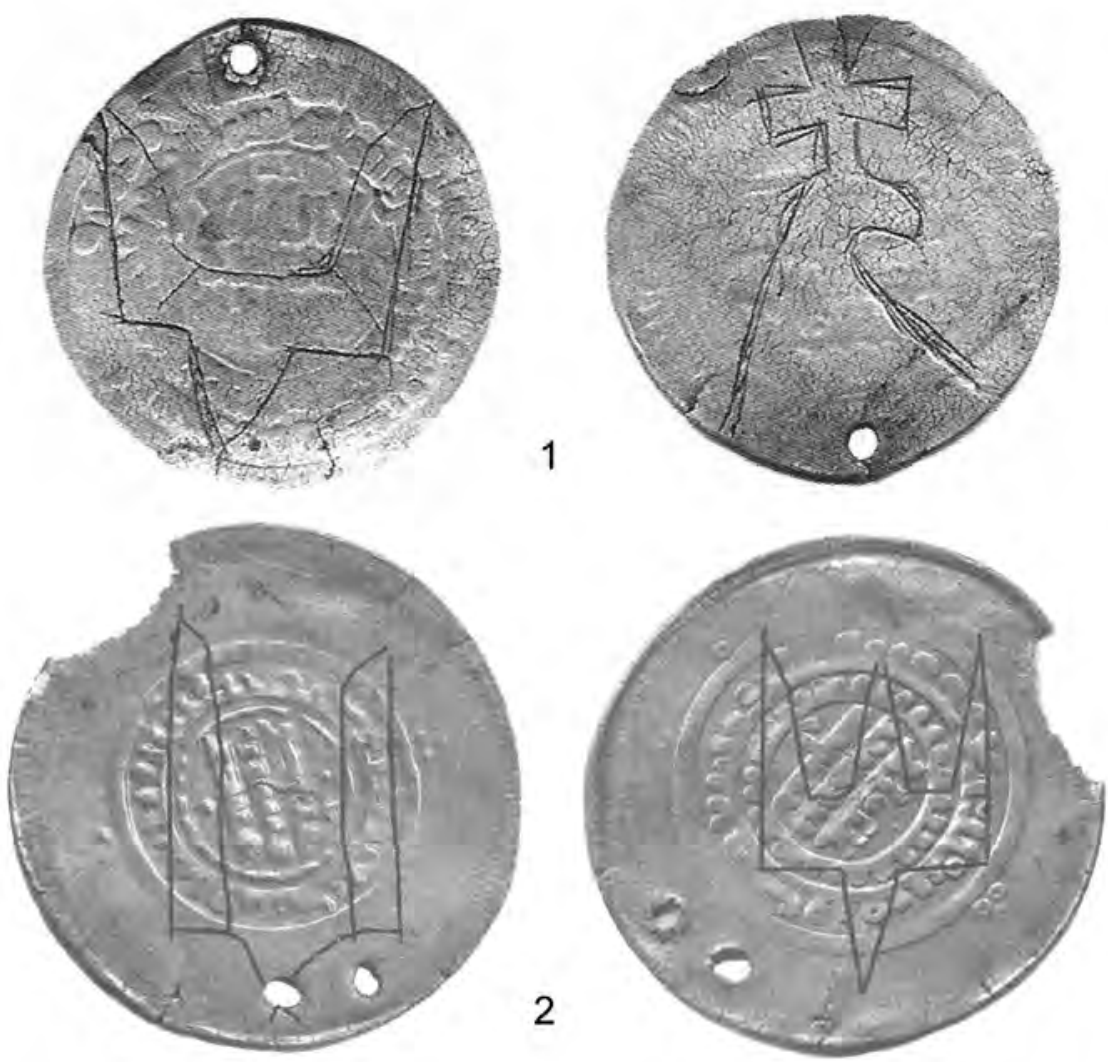

Рис. 9. Двузубцы в граффити на монетах:

1 - Черниговская обл. (?), Украина (?); 2 - Курская обл., Россия, По: Нечитайло 2012, с. 6; Стародубцев, Лебедев 2015, с. 163, рис. 3

монете при жизни Святослава Игоревича, поскольку сама монета, была отчеканена уже после гибели князя. Вероятнее всего, княжеский знак Святослава наследовал без изменений его сын, точно также как Святослав наследовал без изменений двузубец от своего отца. Речь может идти только о старшем сыне Святослава, Ярополке Святославиче, наследовавшем по отцу великокняжеский киевский стол. Монета, несущая граффити № 253 Свода 1994 г., отчеканена в годы правления Ярополка Святославича, так что вероятность нанесения на нее знака именно Ярополка представляется мне весьма высокой. Именно так, кстати говоря, расценил граффити № 253 Е. В. Пчелов (1995, с. 37-38).

Граффито № 82 Свода 1991 г. (Добровольский, Дубов, Кузьменко 1991, с. 140) процарапано на монете из клада, сокрытого около 975 г. (рис. 8:8), так что граффито могло быть нанесено на монету как в годы великого княжения Святослава Игоревича, так и в годы великого княжения Ярополка Святославича. 
Среди граффити на восточных монетах выделяется также группа знаков, напоминающих двузубцы Рюриковичей (рис. 8:1, 2, 9, 10) - у этих знаков имеется треугольная ножка, но зубцы изображены не контуром, а простыми вертикальными линиями. Если эти знаки имеют отношение к двузубцам Рюриковичей, то граффито на монете 877/78 г. (рис. 8:1) из клада, сокрытого в первой половине 880-х годов (Мельникова 1996, с. 47, № 1), было нанесено в годы новгородского княжения Рюрика, а граффито (рис.8:2) на монете 894 г. (Мельникова 1996, с. 47, № 2) - в годы великого княжения Игоря Рюриковича.

Однако граффити (рис. 8:9, 10) на монетах 979/980 г. (Мельникова 1995, № 11) и 988/989 гг. (Мельникова 1995, № 12) процарапаны на монетах, отчеканенных уже после гибели Ярополка. Таким образом, по крайней мере в 80-е - 90-е годы Х в., то есть - в годы великого княжения Владимира Святославича, двузубец продолжал оставаться реально существующим символом власти. Единственным известным представителем старшей ветви рода Рюриковичей в это время был Святополк Ярополчич. Именно он имел право наследовать родовой двузубец. И именно этим обстоятельством объясняют исследователи использование Святополком двузубца (Янин 1970, с. 40; Сотникова, Спасский 1983, с. 82-83).

Признавая возможность использования Святополком родового двузубца Рюриковичей необходимо ответить на вопрос, почему на монетах князя помещен двузубец с крестовидным зубцом, то есть - измененный по сравнению с двузубцем его отца и деда. Ответить на этот вопрос позволяют, как кажется, именно граффити на монетах 979/980 г. и 988/989 гг. По-видимому, Святополк, получив «из руки» великого Киевского князя Владимира Святославича туровский стол, стал в оппозицию к дяде. Он осознавал себя Ярополчичем, то есть - законным претендентом на великий киевский стол, занятый „не по праву” убийцей отца. Есть основания считать, что в своих претензиях на верховную власть Святополк находил достаточно широкую поддержку: об этом свидетельствует не только летописный рассказ о поддержке Святополка вышгородскими боярами (Лавр., стб. 132), но и отмеченное В.И. Татищевым присутствие сторонников Святополка среди новгородцев (Татищев 1963 , с. 238).

Одним из важнейших проявлений оппозиционности Святополка стало, на мой взгляд, именно использование туровским князем родового двузубца ${ }^{7}$. Фактически, это означало претензии Святопролка Ярополчича на верховную власть в государстве. Именно следствием фрондирования стало известное по Хронике Титмара (Древняя Русь 1999, с. 319) заключение Святополка и его жены в темницу по обвинению в заговоре. И именно демонстративное ис-

\footnotetext{
7 Подтверждением использования Святополком Ярополчичем родового двузубца в годы туровского княжения стала, как кажется, находка топорика с изображениями княжеских знаков в кургане могильника Шекшово под Суздалем (Белецкий 2014б, с. 65-72).
} 
пользование родового двузубца могло стать главной причиной ареста Святополка. Победоносный поход на Русь Болеслава Храброго в 1013 г., исследователи не без основания считают «местью Болеслава за заключение в Киеве его дочери и зятя» (Древняя Русь 1999, с. 322). Думается, что именно поход Болеслава на Киев заставил Владимира не только выпустить Святополка из заточения, но и признать за ним право престолонаследия. Кстати, отказ новгородского князя Ярослава Владимировича в 1014 г. платить дань Киеву был, вероятнее всего, реакцией на возвышение Святополка.

Результатом соглашения, достигнутого между Владимиром и Святополком под угрозой продолжения военных действий, стали, очевидно, взаимные уступки: Владимир был вынужден провозгласить Святополка наследником киевского престола, но взамен Святополк был вынужден признать себя вассалом Владимира и внести изменение в форму родового двузубца. Заметим, что изменение это было произведено путем усложнения зубца двузубца, то есть - по образцу изменения формы трезубца при наследовании его сыновьями Владимира.

Возвращаясь к двузубцу из Бодзи, отметим, что знак этот вряд ли можно отнести ко времени великого киевского княжения Игоря Рюриковича $(† 945)$ и уж тем более к временам Рюрика (†879): столь ранняя датировка, безусловно, вступает в противоречие со временем бытования мечей типа Z. C бо́льшим вероятием поясную гарнитуру (и, очевидно, само погребение) следовало бы датировать временем великого княжения Святослава Игоревича (†972 г.), Ярополка Святославича (†980) или Святополка Ярополчича (до 1013/14). На мой взгляд, предпочтительнее связывать деятельность погребенного в могиле Е-864/І молодого воина с князем Святополком Ярополчичем, а не с его отцом или дедом (ср.: Bodzia 2014, s. 214-218 [W. Duczko], 406-407 [M. Kara]).

Если наши рассуждения верны, то изготовление поясной гарнитуры из погребения Е-864/I следует относить к времени туровского княжения Святополка, то есть - к 1008-1013 гг. (Войтович 1992, с. 21).

Завершая комментарии к знаку на ременном наконечнике из могильника Бодзя, мне бы хотелось добавить еще несколько слов. Изображения мечей вырезаны на целом ряде новгородских деревянных цилиндров - бирок, опечатывавших мешки с пушниной (Янин 1982, с. 150). При этом, на двух цилиндрах изображение меча сопровождалось надписью, в которой упомянут „мечник” (Янин 2001, с. 95, 99-100, № 6, 19), на шести цилиндрах просто вырезано изображение меча (Янин 2001, с. 100, 104-107, № 20, 32, 35, 36, 40, 45), а еще на трех цилиндрах мечник упомянут в надписи, но изображение меча отсутствует (Янин 2001, с. 100-101, 103, 108-109, № 21, 30, 50). Таким образом, изображение меча на деревянных бирках-цилиндрах указывало на статус сборщика пушнины - мечник, должное лицо княжеского аппарата в древней Руси.

В.Л. Янин, анализировавший статус мечников, зафиксированный в статьях Русской Правды, полагает, что „мечник” это не только сборщик причитаю- 
щихся князю поступлений, но также воин, член младшей дружины князя (Янин 2001, с. 36-38). Если это так, то не указывает ли схематичное изображение меча на ременном наконечнике из Бодзи на статус погребенного в могиле Е-864/I молодого воина, являвшегося мечником князя Святополка Ярополчича в период его туровского княжения. Впрочем, это, конечно, только догадка.

\section{ЛИТЕРАТУРА}

Амелькин А.О. 1987, Знак на гребне с городища Иднакар (к вопросу о начальном периоде русско -удмуртских контактов). Проблемы изучения древней истории Удмуртии. Ижевск.

[Amel'kin A.O. 1987, Znak na grebne s gorodishta Idnakar (k voprosu o nachal'nom periode russko -udmurtskikh kontaktov). Problemy izucheniia drevneĭ istorii Udmurtii. Izhevsk.]

Андрощук Ф. 2013, Мечи викингов, Київ.

[Androshchuk F. 2013, Mechy vykynhov, Kiïv.]

Археалогія і нумізматыка Беларусі. Эниылллапедыл, Мінск 1993.

[Arkhealoîa i numizmatyka Belarusi. Encyklapedyia, Minsk 1993.]

Бабаев К.В. 2009, Монеты Тмутараканского княжества, М.

[Babaev K.V. 2009, Monety Tmutarakanskogo kniazhestva, M.]

Белецкий С.В. 1996, Начало Пскова, СПб.

- 2000а, Знаки Рюриковичей. Часть первая: X-ХІ вв, СПб.

- 2000б, Зарождение русской геральдики. Stratum plus. СПб. Кишинев-Одесса-Бухарест, № 6.

- 2001, Знаки Рюриковичей. Часть вторая: Знаки ХІІ-ХIII вв. на памятниках сфрагистики (материальк к своду), СПб.

- 2004, Подвески с изображением древнерусских княжеских знаков. „Ладога и Глеб Лебедев”. Восьмые чтения памяти Анны Мачинской, СПб.

- 2011, Две древнерусские геральдические подвески. Археология и история Пскова и Псковской земли. Материалы 57-го заседания, М., Псков.

- 2014a, Древнерусские княжеские знаки в гончарных клеймах. Археология и история Пскова и Псковской земли. Материалы 59 заседания, М., Псков, СПб.

- 2014б, Топорик из Суздальского Ополья. Stratum plus. СПб. Кишинев-Одесса-Бухарест. № 6.

- 2016, Еще раз о геральдической подвеске из раскопок в Пскове в 1976 г. Археология и история Пскова и Псковской земли. Материалы 61 заседания. М.; Псков; СПб.

- 2017, Геральдическая подвеска № 136 и трезубеи Владимира Святославича. Культурний шар. Статті на пошану Гліба Юрійовича Івакіна, Київ.

[Beleckiĭ S.V. 1996, Nachalo Pskova, SPb.

- 2000a, Znaki Riurikovicheř. Chast' pervaia: X-XI vv, SPb.

- 2000b, Zarozhdenie russkoŭ geral,diki. Stratum Plus. SPb. Kishinev-Odessa-Bukharest, № 6.

- 2001, Znaki Riurikovichě. Chast' vtoraîa: Znaki XII-XIII vv. na pamiatnikakh sfragistiki (materialy $k$ svodu), $\mathrm{SPb}$.

- 2004, Podveskis izobrazheniem drevnerusskikh kniazheskikh znakov. „Ladoga i Gleb Lebedev”. Bos'mye chteniia pamiati Anny Machinskoř, $\mathrm{SPb}$.

- 2011, Dve drevnerusskie geral'dicheskie podveski. Arkheologiía Pskova i Pskovskoŭ zemli. Materialy 57-go zasedaniia, M. Pskov.

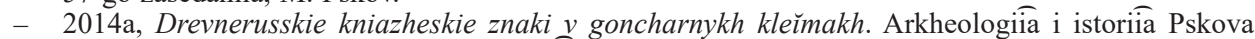
i Pskovskoĭ zemli. Materialy 59 zasedeniia, M. Pskov, SPb.

- 2014b, Toporik iz Suzdal'skogo Opol'ia. Stratum plus. SPb. Kishinev-Odessa-Bukharest. № 6.

- 2016, Eshche raz o geral'dicheskor podveske iz raskopok v Pskove w $1976 \mathrm{~g}$. Arkheologiia i istoriia Pskova i Pskovskoî zemli. Materialy 61 zasedaniia. M. Pskov SPb.

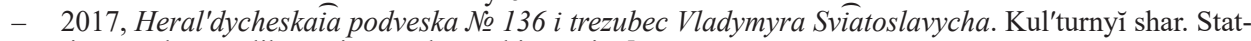
ti na poshanu Hliba Iuriünovycha Ivakina, Kiïv.]

Bodzia. A Late Viking-Age Elite Cemetery in Central Poland, A. Buko (ed.). Leiden: Brill 2014.

Войтович Л.В. 1992, Генеалогія династій Рюриковичів і Гедиміновичів, Київ.

[Voŭtovych L.V. 1992, Henealohiia dynastǐ Riurikovychiv i Hedyminovychiv, Kï̈v.]

Гроздилов Г.П. 1962, Раскопки древнего Пскова. Археологический сборник Государственного Эрмитажа. Вып. 4., Л.

[Grozdilov G.P. 1962, Raskopki drevnego Pskova. Arkheologicheskiĭ sbornik Gosudarstvennogo Ėrmitazha. Vyp. 4., L.] 
Добровольский И.Г., Дубов И.В., Кузьменко Ю.К. 1991, Граффити на восточных монетах. Древняя Русь и сопредельные страны, Л.

[Dobrovol'skiĭ I.G., Dubov I.V., Kuz'menko Iu.K. 1991, Graffiti na vostochnykh monetakh. Drevniaia Rus' i sopredel'nye strany, L.]

Древняя Русь в свете зарубежных источников, М. 1999.

[Drevniaia Rus'v svete zarubezhnykh istochnikov, M. 1999.]

Ершова T.Е. 2010, Серебряная подвеска с изображением тамги Рюриковичей из камерного погребения в Пскове. // Краеугольный камень. Археология, история, искусство, культура России и сопредельных стран. 80-летию со дня рождения Анатолия Николаевича Кирпичникова посвящается. Т. 1, СПб, М.

[Ershova T.E. 2010, Serebrianai்a podveska s izobrazheniem tamgi R̂̃urikovichĕ iz kamernogo pogrebeniïa v Pskove. Kraeugol'n'y̌ kamen'. Arkheologiïa, istorïa, iskusstvo, kul'tura Rossii i sopredel'nykh stran. 80-letiiu so dnia rozhdeniia Anatoliia Nikolaevicha Kirpichnikova posviashchaetcia. T. 1, $\mathrm{SPb} ., \mathrm{M}$.

Ершова Т.Е., Яковлев А.В. 2016, Подвеска со знаком Рюриковичей и изображением птицы с крестом из камерного погребения 6 Старовознесенского некрополя Пскова. Древнерусский некрополь Пскова X - начала XI века. Т. 2. Камерные погребения Пскова. По материалам археологических раскопок 2003-2009 гг. у Старовознесенского монастыря, СПб.

[Ershova T.E., Iakovlev A.V. 2016, Podveska so znakom Riurikovicher i izobrazheniem pticy s krestom iz kamernogo pogrebeniia 6 Starovoznesenskogo nekropolia Pskova. Drevnerusskiu nekropol' Pskova X-nachala XI veka. T. 2. Kamernye pogrebeniia Pskova. Po materialam arkheologicheskikh raskopok 2003-2009 gg. u Starovoznesenskogo monastyria, SPb.]

Кирпичников А.Н. 1966, Древнерусское оружие. Вып. 1. Мечи и сабли IX-ХІІІ вв. Свод археологических источников. Е1-36, М. Л.

[Kirpichnikov A.N. 1966, Drevnerusskoe oruzhie. Vyp. 1. Mechi i sabli IX-XIII vv. Svod arkheologicheskikh istochnikov. E1-36, M. L.]

Королева Э. В. 2016, Подвеска с княжескими знаками из раскопок 1976 г. в Пскове (в продолжение дискуссии). «Археология и история Пскова и Псковской земли». Материалы 61 заседания, М., Псков, СПб.

[Koraleva E.V. 2016, Podveska s kniazheskimi znakami iz raskopok 1976 g. v Pskove (v prodolzhenie diskussii). «Arkheologiia i istoriia Pskova i Pskovskoñ zemli». Materialy 61 zasedaniia, M., Pskov, $\mathrm{SPb}$.]

Krysztofiak T. 2013, Okucie ze znakiem Ruryka znalezione w Gieczu, Archeologia Polski, t. 58, z. 1-2, Warszawa.

Лабутина И.К. 1983, Культурный слой Пскова. Археологическое изучение Пскова. М.

[Labutina I.K. 1983, Kul'turnyı̆ slǒ Pskova. Arkheologicheskoe izuchenie Pskova. M.]

Лабутина И.К., Королева Э.В. 2014, К изучению подвески с княжескими знаками из раскопок 1976 г. в Пскове. „Славяне и иные языци...”. К юбилею Натальи Германовны Недошивиной. Труды Государственного исторического музея. Т. 198, М.

[Labutina I.K., Koroleva Ė.V. 2014, K izucheniiu podveski s kniazheckimi znakami iz raskopok $1976 \mathrm{~g}$. v Pskove. „Slaviane i inye iazyci...”. K iubileiu Natal'i Germanovny Nedoshivinol. Trudy Gosudarstvennogo istoricheskogo muzeia. T. 198, M.]

Лавр. - Лаврентьевская летопись. Полное собрание русских летописей. Т. 1, М. 1962.

[Lavr. - Lavrent'evskaia letopis'. Polnoe sobranie russkikh letopiceľ. T. 1, M. 1962.]

Медведев А.Ф. 1959, Оружие Новгорода Великого. Материалы и исследования по археологии CCCP. № 65, M.

[Medvedev A.F. 1959, Oruzhie Novgoroda Velikogo. Materialy i iccledovaniia po arkheologii SSSR. № $65, \mathrm{M}$.]

Мельникова Е.А. 1995, Граффити на арабских монетах из собраний Украины. Древнейшие государства Восточной Европы. 1994. М.

- 1996, „Знаки Рюриковичей” на восточных монетах. Восточная Европа в древности и средневековье. Политическая структура древнерусского государства. М.

- 1998, «Знаки Рюриковичей» на восточных монетах. Істория Русі - Украіны. Киів.

[Mel'nikova E.A. 1995, Graffiti na arabskikh monetakh iz sobranǐ Ukrainy. Drevneĭshie gosudarstva Vostochnoĭ Evropy. 1994. M.

- 1996, „Znaki Riurikovicheü” na vostochnykh monetakh. Vostochnaia Evropa v drevnosti i srednevekov'e. Politicheskaia struktura drevnerusskogo gosudarstva. M.

- 1998, «Znaki Riurikovichě̌» na vostochnykh monetakh. Istoriia Rusī - Ukrainy. Kī̄v.]

Молчанов А.А. 1982, Еще раз о таманском бронзовом «брактеате». Советская археология. № 3.

- 1986, Верительные знаки киевских князей и древнескандинавские jartegnir. Тезисы докладов $\mathrm{X}$ конференции по изучению Скандинавских стран и Финляндии. М. 
[Molchanov A.A. 1982, Es ĥhche raz o tamanskom bronzovom «brakteate». Sovetskaia arkheologiia. № 3.

- 1986, Veritel'nye znaki kievskikh kniazel i drevneskandinavskie jartegnir. Tezisy dokladov X konferencii po izucheniiu Skandinavskikh stran i Finliandii. M.]

Нахапетян В.Е., Фомин А.В. 1994, Граффити на куфических монетах, обращавшихся в Европе в $I X$-X вв. Древнейшие государства Восточной Европы. Материалы и исследования. 1991 г. М.

[Nakhapetian V.E., Fomin A.V. 1994, Graffiti na kuficheskikh monetakh, obrashchavshikhsia v Evrope $v$ $I X-X v v$. Drevněshie gosudarstva Vostochnoı̆ Evropy. Materialy i issledovaniia 1991 g. M.]

Нечитайло В.В. 2012, Каталог древнерусских печатей Х-ХIII вв. Т. 1. Древнерусские печати великих князей киевских и митрополитов Руси, Киев.

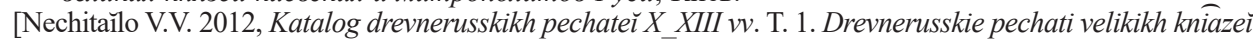
kievskikh i mitropolitov Rusi, Kiev.]

Ольховский В.С. 2001, Тамга (к функции знака). Историко-археологический альманах, 7, Армавир, М.

[Ol'khovskiĭ V.S. 2001, Tamga (k funkcii znaka). Istoriko-arkheologicheskiı̌ al'manakh, 7, Armavir, M.]

Петерсен Я. 2005, Норвежские мечи эпиохи викингов. Типохронологическое изучение оружия эпохи викингов, СПб.

[Petersen İ. 2005, Norvezhskie mechi épiokhi vikingov. Tipokhronologicheskoe izuchenie oruzhiïa épokhi vikingov. $\mathrm{SPb}$.]

Пчелов Е.В. 1995, Еще раз о «знаке Рюриковичей» в свете нумизматических данных. Третья Всероссийская нумизматическая конференция, М.

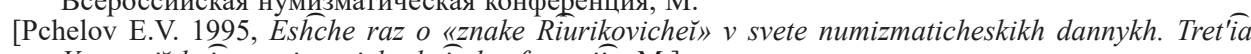
Vserossiüskaia numizmaticheskaîa konferencïa, M.]

Синчук И.И. 1994, О загадочном княжеском знаке на серебрениках с именем „ПЕТОР”. Памятники средневековой культуры. Открытия и версии. Сборник статей к 75-летию В.Д. Белецкого, СПб.

[Sinchik I.I. 1994, O zagadochnom kniazheskom znake na serebrenikah imenem „Petor”. Pamiatniki srednevekovoĭ kul'tury. Otkrytiia i versii. Sbornik stateř k 75-letiiu V.D. Beleckogo, SPb.]

Соломоник Э.И. 1959, Сарматские знаки Северного Причерноморья. Киев.

[Solomonik Ė.I. 1959, Sarmatskie znaki Severnogo Prichernomop'í. Kiev.]

Сорокин И.Ю. 2015, О происхождении и датировке «христианских» подражаний саманидским дирхемам. II Международная нумизматическая конференция „Эпоха викингов в Восточной Европе в памятниках нумизматики VIII-XI вв.”, СПб.

[Sorokin M.P., 2015, O proiskhozhdenii i datirovke «khristianskikh» podpazhanil samanidskim dirhemam. II Mezhdunarodnaia numizmaticheskaia konferenciiia, „Épokha vikingov v Vostochnoĭ Evrope v pamiatnikakh numizmatiki VIII-IX vv.", SPb.]

Сотникова М.П., Спасский И.Г. 1983, Тысячелетие древнейших монет России. Сводный каталог русских монет X-XI веков, Л.

[Sotnikova M.P., Spasskiǔ I.G. 1983, Tysiacheletie drevně̌shikh monet Rossii. Svodnyı̆ katalog russkikh monet $X-X I$ vekov, L.]

Стародубцев Г.Ю., Лебедев В.П. 2015, Клад украмений и монистосо знаками Рюриковичей из Курской области: предварительное сообщение. II Международная нумизматическая конференция „Эпоха викингов в Восточной Европе в памятниках нумизматики VIII-XI вв.”, СПб.

[Starodubcev G. Tu., Lebedev V.P. 2015, Klad ukrashenĭ i monistoso znakami Riurikovichĕ iz Kurskor oblasti: predvaritel'noe soobshchenie. II Mezhdunarodnaia numizmaticheskaia konferenciia „Ëpokha vikingov v Evrope v pamiatnikakh numizmatiki VIII-XI vv.”, SPb]

Татищев В.Н. 1963, История Российская. Т. II, Л.

[Tatishchev V.N. 1963, Istoriïa Rossiǔskaï. T. II, L.]

Трусау̂ А.А., Собаль В.Е., Здановіч Н.I. 1993, Стары замак у Гродне XI-XVIII cm.cm. Гісторыка -археалагічны нарыс, Мінск.

[Trusaû A.A., Sobal' V.E., Zdanovich N.I. 1993, Stary zamak u Hrodne XI-XVIII st.st. Historyka-arkhealahichny narys, Minsk.]

Черепнин Л.В. 1956, Русская палеография, М.

[Cherepnin L.V. 1956, Russkaia paleografiia, M.]

Янин В.Л. 1970, Актовые печати древней Руси X-ХV вв. Т. 1, М. 1970.

- 1982, Археологический комментарий к Русской Правде. Новгородский сборник. 50 лет раскопок Новгорода, М.

- 2001, У истоков новгородской государственности. Великий Новгород.

[Tanin V.L. 1970, Aktovye pechati drevneŭ Rusi X-XV vv. T. 1, M. 1970.

- 1982, Arkheologicheskǐ kommentariü k Russkoŭ Pravde. Novgorodskiı̆ sbornik. 50 let raskopok Novgoroda, M.

- 2001, U istokov novgorodskor̆ gosudarstvennosti. Velikiŭ Novgorod.]

Яџенко С.А. 2001, Знаки-тамги ираноязычных народов древности и раннего средневековья, М.

[Tacenko S.A. 2001, Znaki-tamgi iranoiazychnykh narodov drevnosti i rannego srednevekov'ia, M.] 